\title{
Building Professional Pride in Literacy
}

\author{
A Review by DENYSE EDNEY
}

\section{BUILDING PROFESSIONAL PRIDE IN LITERACY: A DIALOGICAL GUIDE TO PROFESSIONAL DEVELOPMENT FOR PRACTITIONERS OF ADULT LITERACY AND BASIC EDUCATION BY ALLAN QUIGLEY}

Krieger Publishing Company, 2006, P.O. Box 9542, Melbourne, Florida ISBN: 1-57524-262-1, 244 pages. www.krieger-publishing.com

What should professionalism mean in the literacy field? Quigley cites the results of a survey of literacy practitioners. According to one participant, 'To act "professionally" in literacy and adult education is to self-educate in professional development.' Another replied that literacy practitioners act professionally when they view 'students as most valued clients and attempt to engage their individual needs and goals within a high-quality program of basic skills instruction.' The theme of caring was one of the strongest points made. Quigley quoted from another survey participant: 'To act professionally in adult literacy one is service-oriented, friendly and accountable. A professional is ethical (with) strong values, especially those pertaining to literacy and the population one serves'.

Quigley concludes that professionalism in adult literacy and basic education 'appears to be the combination of knowledge and skills, as required in any profession, but it also needs to involve caring, empathy, compassion, ethical conduct, and dedication to the learners' needs'. As an adult literacy educator working on the front lines (Aboriginal Health Literacy in Central Australia), I particularly appreciate and applaud Quigley's summation.

This guide is intended to help practitioners develop as professionals. Discussion questions, professional development activities, and follow-up readings appear at the end of each chapter; each chapter is written to help enhance skills, knowledge and values. Quigley's guide involves the use of learning circles and a learning journal as ways of reflecting on what is happening. A learning journal will capture your thoughts, your reflections, your opinions, your doubts and your successes.

Quigley gives an interesting account of the history of literacy education (in the UK, US and Canada) before giving a rundown on some pros and cons of different adult learning philosophies: liberal, progressive, vocational, humanist and radical. I agree with Quigley that problem-solving, although time-consuming, is worth considering, 'since ownership of learning, the challenge of problem-solving, and finding collaborative ways to achieve relevance are all very powerful methods in adult education'. Quigley also 
reviews some of the basic principles of teaching adults and some of the methods that have proven effective within each of the philosophical approaches.

To act professionally is to bring three essential qualities to adult literacy. What should go into professional conduct in teaching and administering adult literacy? Education and training to build knowledge of the subjects and practice and education or training to build the skills necessary for the job were the first two required elements. But the third element was stressed repeatedly. In adult literacy, a professional needs to be a caring, compassionate, dedicated educator. One is held to a high standard on values in our field.

I recommend this book as a practical way to undertake professional development in the field of adult literacy education. It will, indeed, help build professional pride in literacy. 